\title{
THREE PROBLEMS IN THEOCRITUS XXII
}

Three passages in Theocritus' Idyll XXII which had hitherto caused difficulties to the critics reveal themselves to be, in the light of Hellenistic poetic technique, perfectly sound and congruent with Hellenistic literary conventions.

This poem is a hymn to Castor and Polydeuces. After the introduction, in which the poet states his intention to praise the two heroes, there follow two incidents in which first Polydeuces and then Castor is the main actor. It is with the second incident, the duel between Castor and Lynceus, that I am now concerned (lines I37-2II).

Three problens have been read into this Idyll by critics such as Wilamowitz and Gow. I should like to show that these three problcins do not exist: features which puzzled Gow and Wilamowitz reveal themselves, when examined in the light of Hellenistic epic technique, as typical ingredients of such a technique.

The first problem is the simplest. Gow and Wilamowitz, followed by Dover, seem astonished to see that Lynceus' speech "shows the Dioscuri as wantonly aggressive" ${ }^{1}$. Dover appears unable to account for the fact that "Theokritos seems to accept the lawless brutality of the Dioskouri as a datum» ${ }^{2}$. The perplexity expressed by Gow and Dover derives from their having forgotten that the poem which re are examining is an epyllion, i. e. it is concerned with an epic subject, and, in particular, that there was one school of Hellenistic epic which, in pointed contrast with Apollonius, regarded the very qualities objected to by these critics as an essential element in the characterization of heroes ${ }^{3}$, in strict adherence to the Homeric canons of morality: according to Homer, the Dioscuri were "of the same clay as other heroes", as none other than Gow himself underlines ${ }^{4}$, and in epyllion XXII the Dioscuri are therefore characterized exactly as Homeric heroes.

1 So Gow, Theocritus, vol. II, p. 383.

- Theocritus, London 1975, p. 246.

3 This point has been recently clarified by $\mathrm{G}$. Giangrande in $A C_{4} \mathrm{I}, 1972$, p. $\mathrm{I}_{3} \mathrm{I}$.

- Ad lines 218-20, p. 407 . 
In other words: the feature which perplexes Gorv and Dover, is, of all things, typical of Hellenistic epic.

The second problem concerns an alleged lacuna inserted into the text by Wilamowitz after line I7o: (lines r6g-r8o):

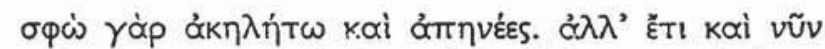

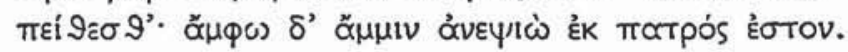

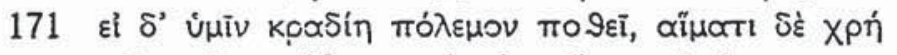

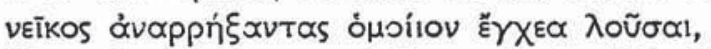

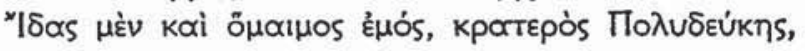

XEipas ह̇

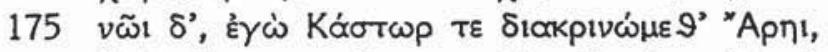

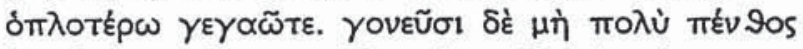

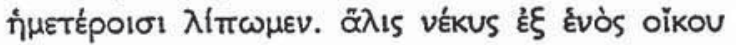

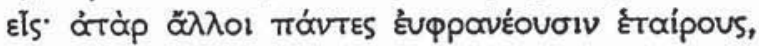

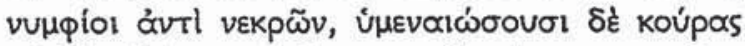

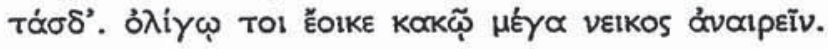

He found himself compelled to insert it into the text in order to postulate that our lines I7rff. were not spoken by Lynceus, but part of an incomplete reply made by Castor. An analysis of the context shows that the lacuna postulated by Wilamowitz and accepted by Gow has no justification.

Gow offers two reasons for the alleged lacuna. First of all, he objects to the fact that Lynceus' speech is not followed by a reply from Castor. The objection is unfounded, as is clear from, of all things, Hellenistic technique: epyllia were, as is well known, a "genre de composition fragmentairen ${ }^{1}$ : not only were they abrupt at the beginning and at the end ${ }^{2}$, but also the unfolding of the story in the middle of the epyllion was characterized by gaps and jumps "senza i traspassi convenzionali dell' epopea" ${ }^{3}$ : in the very epyllion XXII, lines r 35 ff. have "no con-

1 Legrand, Buc. Grecs, 1946, vol. II, p. 68.

2 Cf. Legrand, op. cit., p. 167 ; Giangrande, $C R$ 18, 1968, p. 165.

8 So Pasquali, quoted by Giangrande in $J H S$ 89, 1969, p. 146; on the struncated» structure of epyllia as an (intentional feature», cf. JHS 89 r 969 , pp. I 50 and I5I. As for Idyll XXII, it is obvious that Theocritus was concerned with describing, by means of Lynceus' oratio, the affectus of this hero, after which he jumped saltustim, usprungweis" to the episode of the duel: on this teclunique, cf. J. Heumann, De cpyll. Alexantrino Diss., Leipzig, r904, pp. 53-56. Further bibliography on the gente in F. M. Pontani, L'cpillio greco, Florence, r973. 
nexion with the preceding» ${ }^{1}$, so much so that Gow sees himself compelled to accuse Theocritus of "careless writing", or to suggest that "part is of the Idyll "was originally a separate poem" ${ }^{2}$. To conclude: the lack of connexion noted by Cholmeley between lines I $35 \mathrm{ff}$. and the previous ones is, exactly like the jump from Lynceus' speech to the duel, without Castor's reply, a characteristic trait of epyllia: epyllia consisted in "scene scelte" ${ }^{3}$, not necessarily connected by narration.

The second reason for Gow's insertion of a lacuna after line I70 is that (as he notes ad lines I7rff.), if ömanos means not 'brother' but 'kinsman' (cf. Cholmeley ad line I73 and e. g. Opp. Cyneg. III, 242): (it would be absurd for Lynceus to describe Polydeuces in relation to Idas either as 'his' or 'my kinsman' when his relationship to them both is the same». In reality, an analysis of the context, bearing in mind the point which Lynceus is trying to make - i. e. that there should be no fighting, or as little as possible, between blood-relations - , and the application of the "utrum in alterum" criterion shows that there

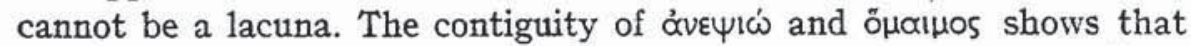
no gap is admissible. Lynceus is anxious to avoid as much blood spilling as possible between blood-relations: he insists that the two opposing

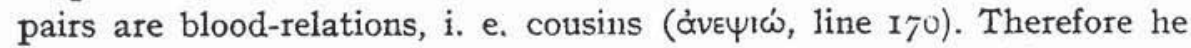
says Idas with reference to the person everybody knew to be his brother, and for whom he evidently was expected to nurture anxiety; with reference to Polydeuces he says öpaınos k̇uós 'my blood-relation', to underline that he is concerned about the latter, qua his blood-relation. If, on the other hand, it were Castor that was speaking, the emphasis which fits into the context, as I have just explained, would be entirely

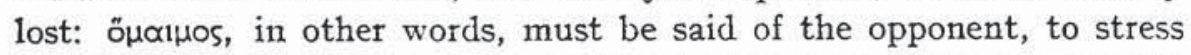

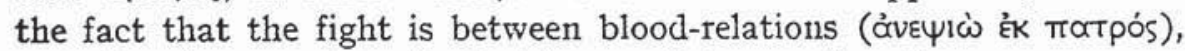
and therefore must be limited to a minimum. For the same reason, in order to adopt a conciliatory tone aimed at reducing the bloodspilling, Idas is left by Lynceus with no laudatory epithet, whereas his opponent's brother, Polydeuces, is praised by means of the word kpart-pós. If the speech were made by Castor, the conciliatory tone at the

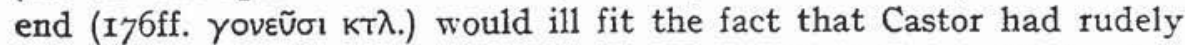
left his opponent's brother Idas without any laudatory epithet, whereas Castor's own brother Polydeuces received the laudatory term кратєроे. The criterion "utrum in alterum" confirms our considerations:

1 Cf. Cholmelev, Theocritus, London r930 ad line 135 .

2 Theocritus, vol II, p. $3^{84}$.

3 Giangrande, JHS 89, 1969, p. I5I. 


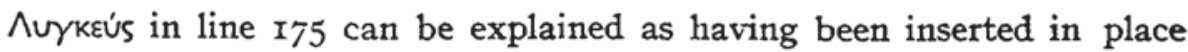

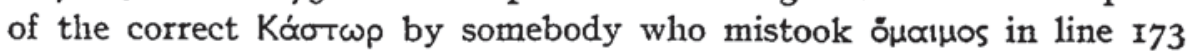
to mean "brother", whereas one could not understand why somebody, finding Kó $\sigma \tau \omega p$ in the mss., should have thought of replacing it by Aujkeús.

After having proposed that the Dioscuri give up their claim to the girls, Lynceus now suggests another plan (lines I7rff.). If, he says, you want to fight, then let Idas and my kinsman Polydeuces stand and watch, while Castor and I, the two youngest, fight a duel. In this way we shall spare our parents great sorrow. Let it be enough for just one of us to dic: (line $17 S$ ):

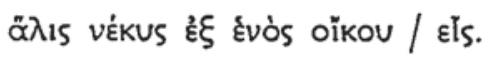

These words are thought by Gow to be ambiguous, and he is not sure whether Theocritus means that there should be one corpse from a single house or one corpse from each house ( $0 p$. cit., p. 403). There is no ambiguity: what Lynceus is suggesting is that there should be only one corpse from one family, i. e. that one or the other of the two cousins should die in the duel so that only one family will suffer grief.

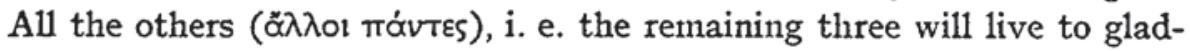
den their parents as bridegrooms, rather than becoming corpses, and will marry the girls. Thus a great quarrel will be ended with the minimum of ill, i. e. by the death of only one, rather than of possibly all of the suitors. Now that we have understood the passage it becomes instantly clear that the word móvtes is not, as Gow thought, "flat and superfluous» but particularly pointed - it refers to the fact, that Lynceus hopes that only one of the four will die in the duel and that there will therefore be three survivors, all of whom will still be able to marry. These are Lynceus' suggestions as to how the trouble can be ended with the loss of only one life.

However, Gow and the commentators see another problcm in the

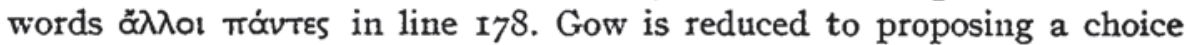
between the excision of lines $178-180$, and saddling Theocritus with a "careless conception of the situation which he is describing". Once more, Theocritus is perfectly careful: Lynceus had just underlined that, besides the two Leucippides kópal (line I3S), there are many other ( $\mu$ upíal) beautiful kópal (lines I5gf.), who could be married

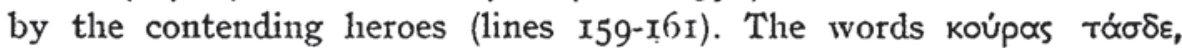
in lines $179-180$, cannot therefore possibly mean "the two Leucippides 
xóparl only: according to Greek, and indeed Theocritean, usage ${ }^{1}$ the words signify "the kópa I have been just talking about», i. e. the Leucippides kópal and the $\mu$ upía kópat. All of the three survivors of the duel, that is, will marry the girls Lynceus had been talking about, i. e. the victor in the duel and his brother will marry the Leucippides, whilst the surviving brother of the hero who is killed in the duel will marry one of the girls mentioned together with the Leucippides by Lynceus. That the two Leucippides will be married by the victor in the duel and his brother, whilst the surviving brother of the hero killed in the duel will have to content himself with one of the other kópal mentioned by Lynceus - an obvious result of the duel - is made in any case

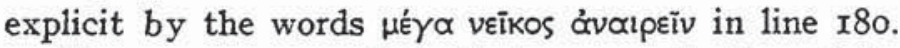

Thus we may conclude that an examination of the wording in the poem, as well as of the way in which the story unfolds in the epyllion, shows that Theocritus was never less than accurate.

I shall now proceed to explain the third problem which has unnecessarily puzzled Gow. Once more, an analysis of the wording will show that Theocritus is completely accurate. Gow (ad lines 2I8-20) criticizes Theocritus for not realizing that the Tyndaridae never were at Troy since at the time of the Trojan war they lay dead and buried in Lacedaemon: he is led to this difficulty by his mistranslation of line 216 at the end of the poem: (lines $212-223$ ):

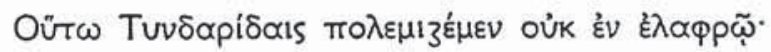

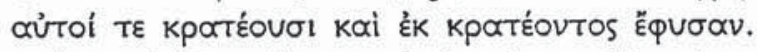

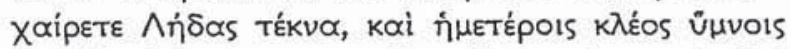

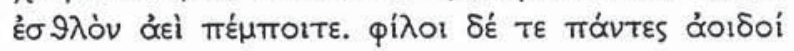

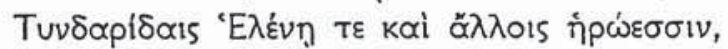

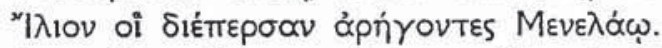

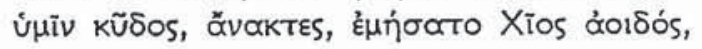

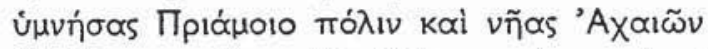

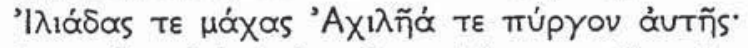

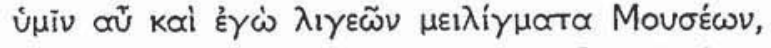

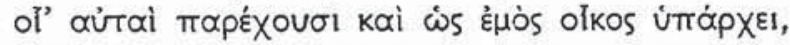

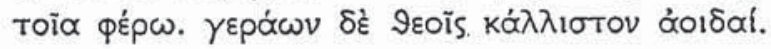

Gow mistranslated lines $215-217$ as 'All bards are dear to the sons of Tyndareus, to Helen, and to the other heroes that aided Menelaus to sack Ilium'. However, as can be seen from such standard dictiona-

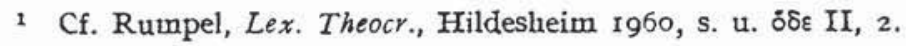


ries as Capelle, Vollständiges Wörterbuch, or LSJ s. u., ở $\lambda \lambda$ os can mean in Homer 'as well, besides': cf. e. g. Od. VI 84.

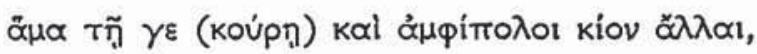

a $u c h$ gingen mit ihr Dienerinnen' (Capelle, op. cit.). Therefore, the sense of lines 2I5ff. is, according to Homeric usage, as accurately followed by Theocritus in his epyllion, 'All bards are dear to the sons of Tyndareus, and to Helen, and a 1 so to the heroes who sacked Ilium, helping Menelaus'. Úniv, in line 2I8, refers to the heroes who sacked

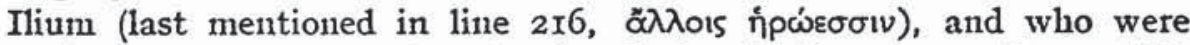
praised by Homer. On the other hand, úniv in line 22I, as the particle aũ clearly shows, refers not to the heroes who were at Troy but to the Tyndaridae, the sense being "but to you, on the other hand $(\alpha \tilde{v}), I$, the poet, offer my songs of praise (just as Homer had praised the heroes who sacked Troy)'.

Conclusion: an analysis of the context and wording has shown that the critics are unjustified in accusing Theocritus of carelessnes: he is, in fact, accurate down to the minutest detail, as befits a Hellenistic poet.

HEATHER WHITE

Birkbeck College

London University 